\title{
Management of acute appendicitis in pregnancy
}

\author{
Gebelikte akut apandisit tedavisi
}

\author{
Selin KAPAN, Mehmet Abdussamet BOZKURT, \\ Ahmet Nuray TURHAN, Murat GÖNENÇ, Halil ALIŞ
}

\section{BACKGROUND}

Acute appendicitis is the most common surgical non-obstetric pathology during pregnancy. In this report, pregnant patients operated with a diagnosis of acute appendicitis in the last three years are evaluated retrospectively.

\section{METHODS}

Between January 2009 and January 2011, 20 pregnant patients were operated for acute appendicitis. Patients were evaluated regarding age, gestational age, clinical and laboratory examinations, imaging studies, operative findings, mean hospital stay, mean operative time, and outcome.

\section{RESULTS}

In 17 of 20 patients, acute appendicitis was confirmed and appendectomy was performed. Ten of the patients were operated with laparoscopic technique and the remaining 10 had open appendectomy. There was no fetal or maternal morbidity or mortality in any patient. All 20 patients delivered healthy babies during the postoperative course.

\section{CONCLUSION}

Acute appendicitis is a challenging diagnosis in the pregnant patient; however, early surgical intervention should be performed with any suspicion. The type of surgery depends on the surgeon's preference and experience.

Key Words: Acute appendicitis; appendectomy; laparoscopy; pregnancy.

\section{$A M A C ̧$}

Akut apandisit gebelikte en sık rastlanan obstetrik diş1 cerrahi patolojidir. Bu yazıda son 3 yılda ameliyat edilen gebelikteki akut apandisit olguları geriye dönük olarak değerlendirildi.

\section{GEREÇ VE YÖNTEM}

Ocak 2009 ve Ocak 2011 arasinda 20 gebe hasta akut apandisit nedeniyle ameliyat edildi. Hastalar yaş, gebelik yaşı, klinik ve laboratuvar bulguları, görüntüleme sonuçları, ameliyat bulguları, ortalama hastanede yatış süresi, ortalama ameliyat süresi ve sonuçlar açısından değerlendirildi.

\section{BULGULAR}

Çalışmaya alınan 20 hastanın 17'sinde apandisit doğrulan$\mathrm{d} 1 \mathrm{ve}$ apendektomi uygulandı. Hastaların 10'u laparoskopik, diğer 10 hasta ise açık ameliyata alındı. Hastaların hiçbirinde fetal morbidite ve mortalite görülmedi. Hastaların tümü ameliyat sonrası gebelik sonunda sağlıklı bebekler doğurdular.

\section{SONUÇ}

Akut apandisit gebe hastada zor bir tanı olmasına rağmen şüphe anında erken cerrahi girişim yapılmalıdır. Cerrahinin tipi cerrahın seçimine ve tecrübesine bağlıdır.

Anahtar Sözcükler: Akut apandisit; apendektomi; laparoskopi; gebelik.
Acute appendicitis is the most common surgical condition requiring non-obstetric abdominal surgery during pregnancy, and its incidence is reported to be between 1:1250 and 1:1500 pregnancies, with $50 \%$ of cases occurring in the second trimester ${ }^{[1-3]}$ The high prevalence of nausea, vomiting and abdominal pain in the normal obstetric patient population leads to the delayed surgical intervention..$^{[4,5]}$ In addition, there is a general reluctance to operate unnecessarily on a gravid patient. In any pregnant patient, right-sided abdominal 
pain, associated with guarding and rebound and accompanied by fever should always be considered appendicitis unless proven otherwise. Assessment of the white blood cell count may not be particularly helpful because pregnant patients often have a physiological leukocytosis. Careful physical examination is key to making the diagnosis. ${ }^{[6]}$ Ultrasonography should be used to assess for the presence of an obstetrical pathology such as an ovarian cyst or torsion of an adnexal mass. In the general population, there are several scoring systems available to aid the accuracy of diagnosis of appendicitis, including the Alvarado scoring system. No such system is available for the obstetric population. ${ }^{[3-5]}$

In this study, we present our cases of acute appendicitis during pregnancy in light of the related literature.

\section{MATERIALS AND METHODS}

Twenty pregnant women who were consulted to the Emergency Surgery Clinic for acute abdominal pain from January 2009 to January 2011 were included in this study. Clinical data collected retrospectively included physical examination findings, age of the patients, week of pregnancy, presenting symptoms, ultrasonographic confirmation, leukocyte count, and postoperative complications. All patients were assessed by a gynecologist and a general surgeon before and after surgery. The diagnosis of acute appendicitis was based on clinical examination, ultrasound (US) and leukocyte count, and pregnancy was confirmed by US. Each patient was evaluated by the Alvarado scoring system. The period between surgical consultation and surgery was evaluated.

Appendectomies were performed by laparoscopic or open approach. General inhalational anesthesia was employed routinely during the operation. Urinary catheters were used routinely.

\section{RESULTS}

The mean age of the patients was 26 (19-35) years. The mean gestational age at the time of LA was 17.6 weeks (4-33 weeks). Ten patients were in the second trimester, 6 were in the first trimester and 4 were in the third trimester of pregnancy. The mean Alvarado score was 7.7 (7-9). The mean leukocyte count was 13920 (7200-22300), and mean neutrophil \% was $81.65 \%$ (91.4\%-67.3\%). All 20 patients were admitted with complaints of abdominal pain. Thirteen patients had additional nausea and vomiting. Abdominal ultrasonography was performed in all patients after gynecological examination. Ultrasonography revealed acute appendicitis in seven patients. All these seven patients were acute appendicitis. In the remaining 13 patients, in whom ultrasonography could not visualize the ap- pendix, acute appendicitis was confirmed in 10 during the operation. The median time between consultation and operation was 6 hours (3-10). The mean operation time was 54.1 minutes (12-135 min). The mean operation time in open and laparoscopic approach was 51.7 $\min (12-120)$ and $56.5 \mathrm{~min}(30-135)$, respectively. The mean hospital stay was 1.1 days (1-2 days). In 8 of the 10 laparoscopic procedures, the first trocar was inserted with open technique; in the remaining, Veress insufflation was performed.

In 10 patients, diagnostic laparoscopy was performed and seven of these patients had acute appendicitis. One patient had paraovarian cyst, whereas the other two patients had no pathology.

In the remaining 10 patients, open appendectomy was performed, and all 10 had acute appendicitis. There was no maternal or fetal mortality, morbidity, or uterine injury in any of the patients. No case of fetal mortality was encountered. Twenty patients delivered 20 healthy infants. Demographic data of the patients are given in Table 1.

\section{DISCUSSION}

Certain anatomic and physiologic changes specific to pregnancy may make the cause of the abdominal pain difficult to ascertain in pregnant patients. ${ }^{[3,4]}$ The uterus becomes an abdominal organ at around 12 weeks' gestation and compresses the underlying abdominal viscera. This enlargement may make it difficult to localize the pain and may also mask or delay peritoneal signs. The laxity of the anterior abdominal wall may also mask or delay peritoneal signs. The ureters became dilated as early as the first trimester and remain dilated into the postpartum period. This distension may lead to urinary stasis, increasing not only the risk of urolithiasis, but also infection. Increasing progesterone increases respiratory drive. Functional residual capacity decreases. Hemostatic changes also add to the challenge of evaluating and caring for pregnant women. Pregnancy produces a thrombogenic state, with two-to-three-fold increase in fibrinogen levels. In pregnancy, physiologic leukocytosis occurs, and in our study, all patients had leukocytosis. ${ }^{[4]}$ Anatomical changes related to the gravid uterus, gestational symptoms, the physiological inflammatory response, and a wider differential diagnosis in pregnant women result in poor diagnostic accuracy, reported to range from $36 \%$ to $86 \%{ }^{[2]}$ Acute appendicitis has a peak incidence in the second and third decades coinciding with the childbearing years, and the incidence in pregnancy appears broadly the same as in the nonpregnant, whereas the rate of perforation and subsequent complications are greater. ${ }^{[2,7]}$

Fetal mortality is given as 5\% after appendicitis, whereas this rate increases to approximately $20 \%$ in a 
Table 1. Demographic data of 20 patients

\begin{tabular}{cccccccccc}
\hline Age & $\begin{array}{c}\text { Gestational } \\
\text { age }\end{array}$ & $\begin{array}{c}\text { Alvarado } \\
\text { score }\end{array}$ & $\begin{array}{c}\text { Leukocyte } \\
\text { count }\end{array}$ & $\begin{array}{c}\text { Neutrophil } \\
(\%)\end{array}$ & US & MPT & $\begin{array}{c}\text { Type of } \\
\text { operation }\end{array}$ & MOT & HT \\
\hline 21 & 20 & 8 & 18000 & 90 & App & 8 & LA & 30 & 1 \\
28 & 11 & 7 & 20100 & 91.4 & Neg & 3 & OA & 50 & 1 \\
27 & 30 & 8 & 11200 & 89.6 & Neg & 4 & OA & 40 & 1 \\
27 & 16 & 8 & 22300 & 91.3 & App & 8 & LA & 50 & 1 \\
24 & 19 & 7 & 7200 & 75 & Neg & 7 & OA & 70 & 2 \\
31 & 20 & 8 & 13300 & 93.1 & App & 6 & OA & 40 & 1 \\
35 & 27 & 9 & 8000 & 71.6 & Neg & 9 & LA & 135 & 1 \\
19 & 18 & 7 & 13900 & 83.2 & App & 3 & OA & 50 & 1 \\
24 & 20 & 8 & 5900 & 81 & Neg & 9 & DL & 30 & 1 \\
25 & 18 & 7 & 15100 & 68.9 & Neg & 8 & DL & 60 & 2 \\
27 & 23 & 8 & 19500 & 89.8 & Neg & 4 & OA & 40 & 1 \\
21 & 6 & 8 & 15700 & 81.1 & App & 5 & OA & 50 & 1 \\
31 & 22 & 7 & 10800 & 75.8 & Neg & 4 & LA & 60 & 1 \\
26 & 18 & 7 & 8800 & 67.3 & Neg & 6 & DL & 65 & 1 \\
23 & 6 & 7 & 15500 & 91.1 & App & 10 & OA & 20 & 1 \\
19 & 9 & 8 & 11600 & 67.4 & App & 9 & OA & 12 & 1 \\
32 & 7 & 8 & 16800 & 78 & Neg & 3 & LA & 60 & 1 \\
26 & 4 & 8 & 17000 & 84.4 & Neg & 4 & LA & 45 & 1 \\
24 & 26 & 8 & 11400 & 68.9 & Neg & 4 & LA & 60 & 1 \\
31 & 33 & 9 & 16300 & 93.2 & Neg & 6 & OA & 120 & 1 \\
\hline
\end{tabular}

DL: Diagnostic laparoscopy; HT: Hospitalization time (days); LA: Laparoscopic approach; MOT: Mean operation time (minute); MPT: Time period between consultation and operation (hours); Neg: Negative; OA: Open approach.

perforated appendicitis. Similarly, maternal mortality also increases in perforated cases. ${ }^{[3]}$

Given the lack of sensitivity of the preoperative evaluation, it is not surprising that the pathologic diagnosis of appendicitis is confirmed in $36-50 \%$ of cases. ${ }^{[5]}$ In our study with laparoscopy, three patients were determined to have no acute appendicitis. Seventeen of 20 patients were diagnosed as appendicitis, and pathologic investigation of the 17 specimens confirmed our diagnosis.

The accuracy of the diagnosis is greater in the first trimester, but more than $40 \%$ of patients who undergo appendectomy in the second and third trimester have a normal appendix. The negative laparotomy rate for suspected appendicitis in obstetric cases is $25-50 \%$, compared with $15-35 \%$ in general surgical cases in non-obstetric patients. ${ }^{[2]}$ In our study, 10 of 20 patients were second trimester, and three of them went to negative laparoscopy.

It has been nearly 100 years since Balber stated that 'the mortality of appendicitis complicating pregnancy is the mortality of delay'. The wisdom of this statement has been repeatedly demonstrated. Delay in the diagnosis of appendicitis is associated with significant complications. ${ }^{[2]}$ Delay to surgery is equally risky, with rates of fetal loss reported to be $1.5-4 \%$ in uncomplicated appendicitis compared with $21-35 \%$ in the presence of ruptured appendicitis. ${ }^{[2]} \mathrm{A}$ fetal loss rate of $3-5 \%$ is observed with an unruptured appendix; this rate increases up to $20 \%$ if the appendix is ruptured. The risk of preterm labor is greatest during the first week after surgery, but preterm delivery is rare. ${ }^{[4,8]}$ Furthermore, increasing gestational age reduces diagnostic accuracy and is associated with increased rates of appendiceal perforation and hence complications. ${ }^{[2,9]}$ We operated the patients in our series within 12 hours. Contrary to the literature, in our study, there was no fetal loss or appendiceal perforation. The reason for this difference was the short time period between consultation and operation in our study.

The authors suggest that none of the clinical parameters investigated is useful in predicting appendicitis in pregnancy. US and magnetic resonance imaging (MRI) are not associated with ionizing radiation, have not been shown to have any deleterious effects on pregnancy, and should be used when feasible. ${ }^{[4,9-11]}$ Retrospective studies have suggested that MRI of the appendix is useful in delineating the presence of appendicitis in pregnant women, but the small number of patients in these studies limits the inference that can be drawn. ${ }^{[12]}$ There are also studies using computed tomography (CT) for the diagnosis of acute appendicitis in pregnancy; however, due to the deleterious effects of ionizing radiation on the fetus, it is suggested to be used only in severe trauma patients with pregnancy. 
[4,13-15] Wallace et al. ${ }^{[10]}$ reported an overall negative appendectomy rate of $37 \%$ for pregnant patients with presumed acute appendicitis. They also reported no difference in the negative appendectomy rate with the addition of CT scan after US. We did not use MRI, only physical examination with US. However, we operated 13 patients with normal ultrasonographic findings, and only three patients in this group went to negative laparoscopy (15\%).

Currently, accumulating data support the use of laparoscopy regarding safety and efficacy in all trimesters of pregnancy for acute abdomen. ${ }^{[1,16-18]}$ Laparoscopy is associated with decreased hospital stay, quicker return of bowel function, less postoperative pain, and smaller chance of wound infection and hernia. ${ }^{[3,19]}$ Hasson trocar and Veress needle can be used for insufflation; however, we preferred open technique for first trocar insertion in eight patients. Many studies have demonstrated no increased fetal risk with laparoscopic procedures. ${ }^{[20-24]}$ Critics of laparoscopy in pregnant patients raise concerns over the possible effects of laparoscopic intervention on the developing fetus and emphasize that the limited literature regarding laparoscopic appendectomy is concerning. ${ }^{[25-28]}$ The laparoscopic approach has several advantages over open technique. The position of the incision over the displaced appendix is no longer an issue with a minimally invasive approach. In our opinion, the success of the laparoscopy depends on the surgeon's experience and skills. Another benefit of diagnostic laparoscopy is that it decreases the number of false-positive appendectomies performed. ${ }^{[1]}$ In our study, the overall negative appendectomy rate was $15 \%$, and all of them were diagnosed by laparoscopy. The higher rate of negative appendectomy in the laparoscopic group might reflect a surgical trend during pregnancy in which early diagnostic laparoscopy is considered minimally invasive and safer than observation and re-evaluation. The latter approach can reduce the negative appendectomy rate but might raise the perforation rate. That is why we did not hesitate to perform surgery in our clinic. It should be considered that it is not the laparoscopic approach itself, but the type of infection and delay in diagnosis that are the principal causes of adverse effects attributed to laparoscopy during pregnancy. In our series, no adverse effects on the fetus or the pregnancy were observed after surgery.

Several studies have revealed that the performance of early diagnostic laparoscopy is beneficial when appendicitis is suspected. ${ }^{[29-31]}$ We operated 10 patients within 12 hours with laparoscopic approach. We used open technique for the first trocar insertion. We discharged patients within 24 hours postoperatively.

The symptom/sign complex does not sufficiently diverge from other causes of abdominal pain during pregnancy. There is no current possibility of developing a sufficiently accurate scoring system as in the non-pregnant patients. There is also increasing competence in the use of laparoscopy in pregnancy. ${ }^{[2]}$

In view of the facts of rare occurrence but increased incidence of perforation in the third trimester and increased fetal mortality in perforated cases, early surgery should be considered in any pregnant patient suspected as having acute appendicitis. The type of surgery, whether open or laparoscopic approach, depends on the experience and preference of the surgeon.

Conflict-of-interest issues regarding the authorship or article: None declared.

\section{REFERENCES}

1. Upadhyay A, Stanten S, Kazantsev G, Horoupian R, Stanten A. Laparoscopic management of a nonobstetric emergency in the third trimester of pregnancy. Surg Endosc 2007;21:13448.

2. Brown JJ, Wilson C, Coleman S, Joypaul BV. Appendicitis in pregnancy: an ongoing diagnostic dilemma. Colorectal Dis 2009;11:116-22.

3. Turhan AN, Kapan S. Akut apandisit. In: Ertekin C, Güloğlu R, Taviloğlu K, editors. Acil cerrahi. İstanbul: Nobel Tıp Kitabevleri; 2009. p. 301-16.

4. Kilpatrick CC, Monga M. Approach to the acute abdomen in pregnancy. Obstet Gynecol Clin North Am 2007;34:389-402, $\mathrm{x}$.

5. Stone K. Acute abdominal emergencies associated with pregnancy. Clin Obstet Gynecol 2002;45:553-61.

6. Butala P, Greenstein AJ, Sur MD, Mehta N, Sadot E, Divino CM. Surgical management of acute right lower-quadrant pain in pregnancy: a prospective cohort study. J Am Coll Surg 2010;211:490-4.

7. Coleman MT, Trianfo VA, Rund DA. Nonobstetric emergencies in pregnancy: trauma and surgical conditions. Am J Obstet Gynecol 1997;177:497-502.

8. Mourad J, Elliott JP, Erickson L, Lisboa L. Appendicitis in pregnancy: new information that contradicts long-held clinical beliefs. Am J Obstet Gynecol 2000;182:1027-9.

9. Terzi A, Yildiz F, Vural M, Coban S, Cece H, Kaya M. A case series of 46 appendectomies during pregnancy. Wien Klin Wochenschr 2010;122:686-90.

10. Wallace CA, Petrov MS, Soybel DI, Ferzoco SJ, Ashley SW, Tavakkolizadeh A. Influence of imaging on the negative appendectomy rate in pregnancy. J Gastrointest Surg 2008; 12:46-50.

11. Kilpatrick CC, Orejuela FJ. Management of the acute abdomen in pregnancy: a review. Curr Opin Obstet Gynecol. 2008;20:534-9.

12. Blumenfeld YJ, Wong AE, Jafari A, Barth RA, El-Sayed YY. MR imaging in cases of antenatal suspected appendicitis-a meta-analysis. J Matern Fetal Neonatal Med 2011;24:485-8.

13. Patel SJ, Reede DL, Katz DS, Subramaniam R, Amorosa JK. Imaging the pregnant patient for nonobstetric conditions: algorithms and radiation dose considerations. Radiographics 2007;27:1705-22.

14. Patel SJ, Reede DL, Katz DS, Subramaniam R, Amorosa JK. Imaging the pregnant patient for nonobstetric conditions: algorithms and radiation dose considerations. Radiographics 2007;27:1705-22. 
15. Ames Castro M, Shipp TD, Castro EE, Ouzounian J, Rao P. The use of helical computed tomography in pregnancy for the diagnosis of acute appendicitis. Am J Obstet Gynecol 2001;184:954-7.

16. Jeong JS, Ryu DH, Yun HY, Jeong EH, Choi JW, Jang LC. Laparoscopic appendectomy is a safe and beneficial procedure in pregnant women. Surg Laparosc Endosc Percutan Tech 2011;21:24-7. doi: 10.1097/SLE.0b013e3182051e44.

17. Corneille MG, Gallup TM, Bening T, Wolf SE, Brougher C, Myers JG, et al. The use of laparoscopic surgery in pregnancy: evaluation of safety and efficacy. Am J Surg 2010;200:363-7.

18. de Bakker JK, Dijksman LM, Donkervoort SC. Safety and outcome of general surgical open and laparoscopic procedures during pregnancy. Surg Endosc 2011;25:1574-8.

19. Kapan S, Kapan M. Gebelik ve akut karın. Türkiye Klinikleri Cerrahi Tıp Bilimleri Dergisi 2005;4:84-9.

20. Cohen-Kerem R, Railton C, Oren D, Lishner M, Koren G. Pregnancy outcome following non-obstetric surgical intervention. Am J Surg 2005;190:467-73.

21. Ortega AE, Hunter JG, Peters JH, Swanstrom LL, Schirmer B. A prospective, randomized comparison of laparoscopic appendectomy with open appendectomy. Laparoscopic Appendectomy Study Group. Am J Surg 1995;169:208-13.

22. Pedersen AG, Petersen OB, Wara P, Rønning H, Qvist N, Laurberg S. Randomized clinical trial of laparoscopic versus open appendicectomy. Br J Surg 2001;88:200-5.

23. Sauerland S, Lefering R, Neugebauer EA. Laparoscopic versus open surgery for suspected appendicitis. Cochrane Data- base Syst Rev 2004;4:CD001546.

24. Oelsner G, Stockheim D, Soriano D, Goldenberg M, Seidman DS, Cohen SB, et al. Pregnancy outcome after laparoscopy or laparotomy in pregnancy. J Am Assoc Gynecol Laparosc 2003;10:200-4.

25. Costantino GN, Vincent GJ, Mukalian GG, Kliefoth WL Jr. Laparoscopic cholecystectomy in pregnancy. J Laparoendosc Surg 1994;4:161-4.

26. Motew M, Ivankovich AD, Bieniarz J, Albrecht RF, Zahed B, Scommegna A. Cardiovascular effects and acid-base and blood gas changes during laparoscopy. Am J Obstet Gynecol 1973; 115:1002-12.

27. Ivankovich AD, Miletich DJ, Albrecht RF, Heyman HJ, Bonnet RF. Cardiovascular effects of intraperitoneal insufflation with carbon dioxide and nitrous oxide in the dog. Anesthesiology 1975;42:281-7.

28. Thomas SJ, Brisson P. Laparoscopic appendectomy and cholecystectomy during pregnancy: six case reports. JSLS 1998;2:41-6.

29. Jackson H, Granger S, Price R, Rollins M, Earle D, Richardson W, et al. Diagnosis and laparoscopic treatment of surgical diseases during pregnancy: an evidence-based review. Surg Endosc 2008;22:1917-27.

30. Lemieux P, Rheaume P, Levesque I, Bujold E, Brochu G. Laparoscopic appendectomy in pregnant patients: a review of 45 cases. Surg Endosc 2009;23:1701-5.

31. Turhan AN, Kapan S, Kütükçü E, Yiğitbaş H, Hatipoğlu S, Aygün E. Comparison of operative and non operative management of acute appendicitis. Ulus Travma Acil Cerrahi Derg 2009; 15:459-62. 